\title{
Pollutant removal in subsurface wastewater infiltration systems with/without intermittent aeration under different organic pollutant loadings
}

\author{
Hexin Fei ${ }^{1 \#}$, Deli Tong ${ }^{1 \#}$, Jing Pan ${ }^{1 *}$, Yang Zhang ${ }^{1}$, Linli Huang ${ }^{1}$, Fan Cheng' and Fanping Zheng ${ }^{1}$ \\ ${ }^{1}$ College of Life Science, Shenyang Normal University, 253, Huanghe Street, Shenyang 110034, China
}

\begin{abstract}
Organic pollutant and nitrogen removal performance of subsurface wastewater infiltration systems (SWISs) with and without intermittent aeration, and operated under different organic pollutant loadings, was investigated. The intermittent aeration strategy not only significantly increased removal rates of organic pollutants and $\mathrm{NH}_{4}^{+}-\mathrm{N}$, but also successfully created aerobic conditions at a depth of $50 \mathrm{~cm}$ and did not change anoxic or anaerobic conditions at a depth of 80 and $110 \mathrm{~cm}$, resulting in high TN removal. Increasing organic pollutant loading did not affect the removal of organic pollutants and nitrogen in intermittent aerated SWISs. High removal rates of COD (98.0\% 98.4\%), $\mathrm{NH}_{4}^{+}-\mathrm{N}(93.8 \% \sim 98.1 \%)$ and TN $(84.5 \% \sim 94.0 \%)$ were simultaneously obtained in intermittent aerated SWISs for organic pollutant loadings ranging from 7.4 to $29.1 \mathrm{~g} \mathrm{COD} /\left(\mathrm{m}^{2} \cdot \mathrm{d}\right)$, and these removal rates were significantly higher than for non-aerated SWISs. The results suggest that intermittent aeration is a reliable option to achieve high nitrogen removal in SWISs, especially with high organic pollutant loading.
\end{abstract}

Keywords: subsurface wastewater infiltration system, intermittent aeration, oxidation reduction potential, organic pollutant loading, pollutants removal

\section{INTRODUCTION}

Ninety-five per cent of decentralized wastewater around the world is discharged into the environment without any treatment (Zhang et al., 2006). Subsurface wastewater infiltration systems (SWISs) can provide effective treatment of decentralized wastewater due to integrated mechanisms of chemical, physical and biological reactions that take place as it passes through the soil infiltration system (Fan et al., 2013; Zhang et al., 2005). Such systems are widely used in North America, Europe and Asia as a necessary and appropriate alternative to centralized treatment facilities (Li et al., 2012). Although a SWIS may achieve satisfactory $\mathrm{COD}, \mathrm{TP}, \mathrm{NH}_{4}^{+}-\mathrm{N}$ and $\mathrm{SS}$ removal performance under low pollutant loading rate, TN removal efficiency remains a major challenge for conventional SWISs. Complete TN removal relies firstly on efficient nitrification for ammonia nitrogen $\left(\mathrm{NH}_{4}{ }^{+} \mathrm{N}\right)$ removal, and then requires a source of sufficient organic carbon in denitrification to eliminate nitrate permanently. Intermittent aeration has proven to be an effective method to enhance nitrification (Pan et al., 2015). Moreover, alternate aerobic and anaerobic conditions can be well developed by intermittent aeration which is favourable for nitrification and denitrification. Organic pollutant and nitrogen removal performance of SWISs has been shown to be heavily dependent on pollutant loading (Li et al., 2012), but this may have been a result of changing influent concentration. In particular, when conventional SWISs were applied under high organic pollutant loading, the effluent quality was often not satisfactory and far above the discharge standards (Li et al., 2011). So far, however, few attempts have been made to investigate the effect of organic pollutant loading

\# These authors contributed equally to this study and share first authorship.

* To whom all correspondence should be addressed.

ธ +86 24 86593328; e-mail: crystalpan78@126.com

Received 2 March 2016; accepted in revised form 6 September 2016 on treatment performance of SWISs, especially for intermittently aerated SWISs.

In this study we examined the performance of 6 batch-operated SWISs, operated in parallel, with and without intermittent aeration, for treatment of simulated domestic wastewaters under different organic pollutant loadings. The main purpose of this study was to investigate the characteristic of matrix oxidation reduction potential (ORP) level between the SWIS units, and to evaluate the nitrogen and COD removal performance under different organic pollutant loadings with and without intermittent aeration. The results may provide a more complete understanding of wastewater treatment performance in SWISs, particularly in the combination of intermittent aeration and with different organic pollutant loadings.

\section{MATERIALS AND METHODS}

\section{System description and operation}

Six microcosm SWISs made from clear plexiglass $(120 \mathrm{~cm}$ in height and with $50 \mathrm{~cm}$ internal diameter) were installed in parallel in a greenhouse environment, which were operated under different conditions (in Fig.1). Pt electrodes coupled with calomel electrodes were buried in advance at a depth of 50, 80 and $110 \mathrm{~cm}$ to monitor ORP of pilot systems. A $10 \mathrm{~cm}$ layer of deep gravel (10-20 $\mathrm{mm}$, diameter) was prepared at the bottom to support the infiltration system and evenly distribute the treated water. Wastewater was continuously fed into each SWIS at a hydraulic loading of $0.06 \mathrm{~m}^{3} /\left(\mathrm{m}^{2} \cdot \mathrm{d}\right)$, from a feed tank through a rubber hose with flow rate control valves. A crossing distribution pipe with holes $(0.1 \mathrm{~cm}$ internal diameter) was installed at a depth of $50 \mathrm{~cm}$ below the surface. Gravel particles $(10-20 \mathrm{~mm}$, diameter) were placed around the distribution pipe. The treated wastewater was collected at the bottom of the column near the 
outlet. Each infiltration system was filled with the same matrix consisting of an 80:20 (weight \%) mix of brown soil and cinder.

The six SWISs were divided into three groups operated with different organic pollutant loadings $(a, b, c)$. The same organic pollutant loading was applied to a set of two SWISs, one of which was installed with an aeration unit at a depth of $40 \mathrm{~cm}$ (SA) and had 4 aerated/non-aerated cycles $(\mathrm{A} / \mathrm{N})$ every day. In each $\mathrm{A} / \mathrm{N}$ cycle, the system was firstly subjected to aeration for $1 \mathrm{~h}$ with an airflow rate of $2 \mathrm{~L} / \mathrm{min}$, and then had $5 \mathrm{~h}$ interval without aeration. The aeration would begin at 0:00, 06:00, 12:00 and 18:00. The other SWISs subjected to the same organic pollutant loading was composed without an aeration unit (SB).

In order to minimize variability in the experiment, synthetic wastewater was used. The composition of synthetic wastewater imitated domestic wastewater in China, which is composed of dissolved pollutants without solids. The pollutant loading was manipulated by changing the content of glucose and $\left(\mathrm{NH}_{4}\right)_{2} \mathrm{SO}_{4}$, which resulted in three different organic pollutant loadings (a: $7.4 \mathrm{~g} \mathrm{COD} /\left(\mathrm{m}^{2} \cdot \mathrm{d}\right)$, b: $14.8 \mathrm{~g} \mathrm{COD} /\left(\mathrm{m}^{2} \cdot \mathrm{d}\right), \mathrm{c:}: 29.1 \mathrm{~g} \mathrm{COD} /$ $\left.\left(\mathrm{m}^{2} \cdot \mathrm{d}\right)\right)$. Synthetic wastewater composed of $137,245,461 \mathrm{mg} / \mathrm{L}$ glucose; 45, 74, $163 \mathrm{mg} / \mathrm{L}\left(\mathrm{NH}_{4}\right)_{2} \mathrm{SO}_{4} ; 13 \mathrm{mg} / \mathrm{L} \mathrm{KH}_{2} \mathrm{PO}_{4}, 10 \mathrm{mg} / \mathrm{L}$ $\mathrm{MgSO}_{4}, 10 \mathrm{mg} / \mathrm{L} \mathrm{MnSO}_{4}, 10 \mathrm{mg} / \mathrm{L} \mathrm{ZnSO}{ }_{4} \cdot 7 \mathrm{H}_{2} \mathrm{O}, 6 \mathrm{mg} / \mathrm{L} \mathrm{NaNO}_{3}$, $10 \mathrm{mg} / \mathrm{L} \mathrm{FeSO}_{4}$ and $10 \mathrm{mg} / \mathrm{L} \mathrm{CaCl}_{2}$ was used in this study. The experiment began in September 2014 and lasted for more than 3 months. During the experimental period, temperature was kept at $22 \pm 2^{\circ} \mathrm{C}$.

\section{Sampling and analytical methods}

The six SWISs were operated 2 months before sampling to allow the systems to mature. Influent and effluent water samples were collected every 10 days at 06:00, 14:00 and 22:00, and then analysed for COD, $\mathrm{TN}, \mathrm{NH}_{4}^{+}-\mathrm{N}, \mathrm{NO}_{3}^{-}-\mathrm{N}$ and $\mathrm{NO}_{2}^{-}-\mathrm{N}$ (APHA, 2003) to assess transformation of organic matter and nitrogen. Composite samples were used in each analysis. All analyses were conducted in triplicate and the mean values for the three analyses were reported.

\section{RESULTS AND DISCUSSION}

\section{ORP profiles in an aerated/non-aerated cycle}

Soil ORP has been widely used instead of dissolved oxygen (DO) concentration to indicate soil aeration conditions (Ong et al., 2010). DO concentrations can be used to separate aerobic and anaerobic conditions; however, it is challenging to differentiate between anoxic and anaerobic conditions using DO concentrations. In contrast, different redox conditions are easily distinguished through the ORP profile of a system. Redox potentials greater than $100 \mathrm{mV}$ are commonly interpreted as being indicative of an aerobic environment, whereas less than $-100 \mathrm{mV}$ indicates an anaerobic environment. ORP values between $-100 \mathrm{mV}$ and $100 \mathrm{mV}$ are used to represent anoxic conditions (Zhong et al., 2014). Fig. 2 shows the ORP profiles in an aerated/non-aerated cycle in six SWISs. The difference was distinct between the SWISs with intermittent aeration and without aeration. Under 7.4, 14.8 and $29.1 \mathrm{~g} \mathrm{COD} /\left(\mathrm{m}^{2} \cdot \mathrm{d}\right)$ loadings, the average ORP was $-32.8 \sim-69.3 \mathrm{mV},-148.2 \sim-186.2 \mathrm{mV}$, and $-232.1 \sim-283.6 \mathrm{mV}$, at a depth of 50,80 and $110 \mathrm{~cm}$ in SBs, respectively, which indicates that the non-aerated systems were under anoxic or anaerobic conditions. In the vertical plane, previous work has suggested that ORP decreases with depth (Ding et al., 2014). Previous studies by Zhang et al. (2005) showed that the oxygen from air

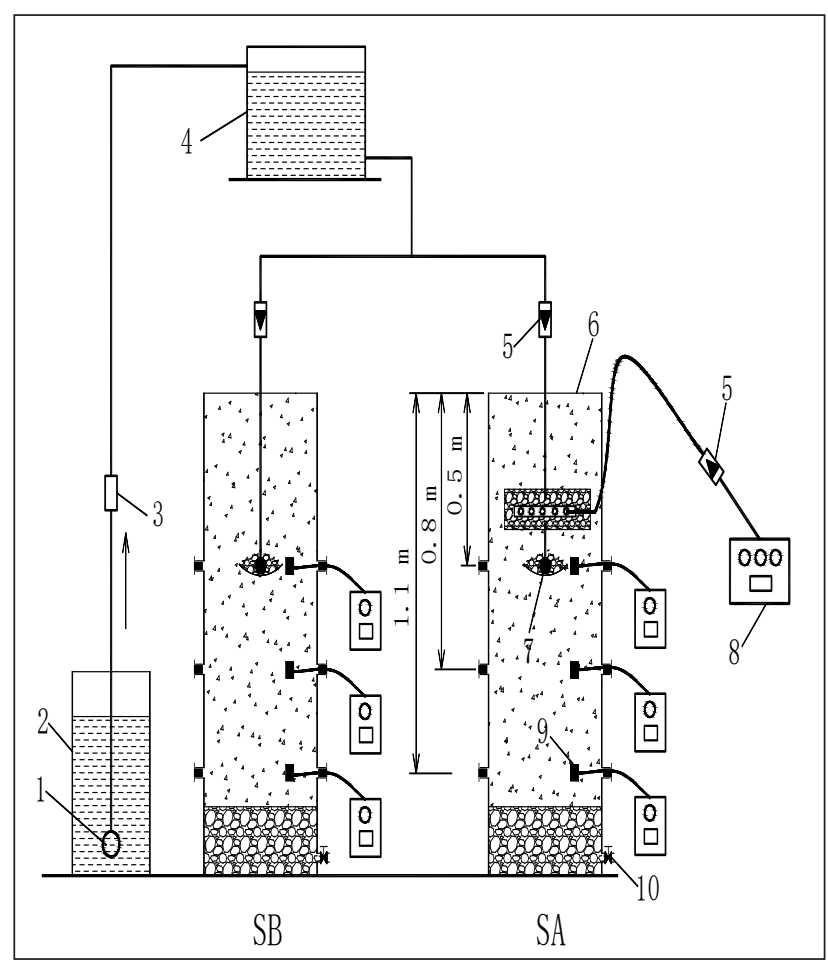

Figure 1

Schematic diagram of two subsurface infiltration systems: (1) submerged pump; (2) wastewater tank; (3) control valve; (4) high-level tank; (5) flow meter; (6) infiltration system body; (7) distributing pipe; (8) air compressor; (9) electrodes; (10) outlet

diffused into the matrix was limited and the prevailing conditions in the SWIS were anoxic or anaerobic below the distribution pipe. The average ORP in SAs was significant higher than that in SBs at $50 \mathrm{~cm}$ depth and under the same organic pollutant loading $(P<0.01)$. As for the average ORP change in SAs, a similar tendency was observed at all depths, i.e., matrix ORP increased in the aerated period, but decreased slowly in the nonaerated period. The average ORP could be more than $202 \mathrm{mV}$ during aeration and as high as $114.9 \mathrm{mV}$ when supplementary aeration was turned off, at a depth of $50 \mathrm{~cm}$. However, at depths of 80 and $110 \mathrm{~cm}$, the average ORP was $-68.3 \sim-31.6 \mathrm{mV}$ and $-189.3 \sim-142.7 \mathrm{mV}$ during aeration, and was $-125.3 \sim-95.2 \mathrm{mV}$ and $-240 \sim-202.5 \mathrm{mV}$ without aeration, respectively. In contrast, aerobic conditions were effectively developed at $50 \mathrm{~cm}$ depth and anoxic or anaerobic conditions were not changed at depths of 80 and $110 \mathrm{~cm}$ within SAs by intermittent aeration. High aerationinduced ORP values may be reduced by the decomposition of nutrients and organic matter, which may explain the tendency for ORP to decrease in the non-aerated period. Moreover, ORP decreased with increasing organic pollutant loading in SAs and SBs. This phenomenon could be explained by the fact that more oxygen would be consumed by biological oxidation of excess organic matter.

\section{Effect of organic pollutant loading on organic pollutant removal}

As seen from Fig. 3, the average effluent COD concentrations were $19.35,46.52$ and $140.40 \mathrm{mg} / \mathrm{L}$, with removal rates of $85.6 \%$, $81.0 \%$ and $71.1 \%$ under different organic pollutant loadings (a, $\mathrm{b}$ and c) in SBs. With the increase in organic pollutant loading, the limitation of oxygen became more obvious, and resulted in 

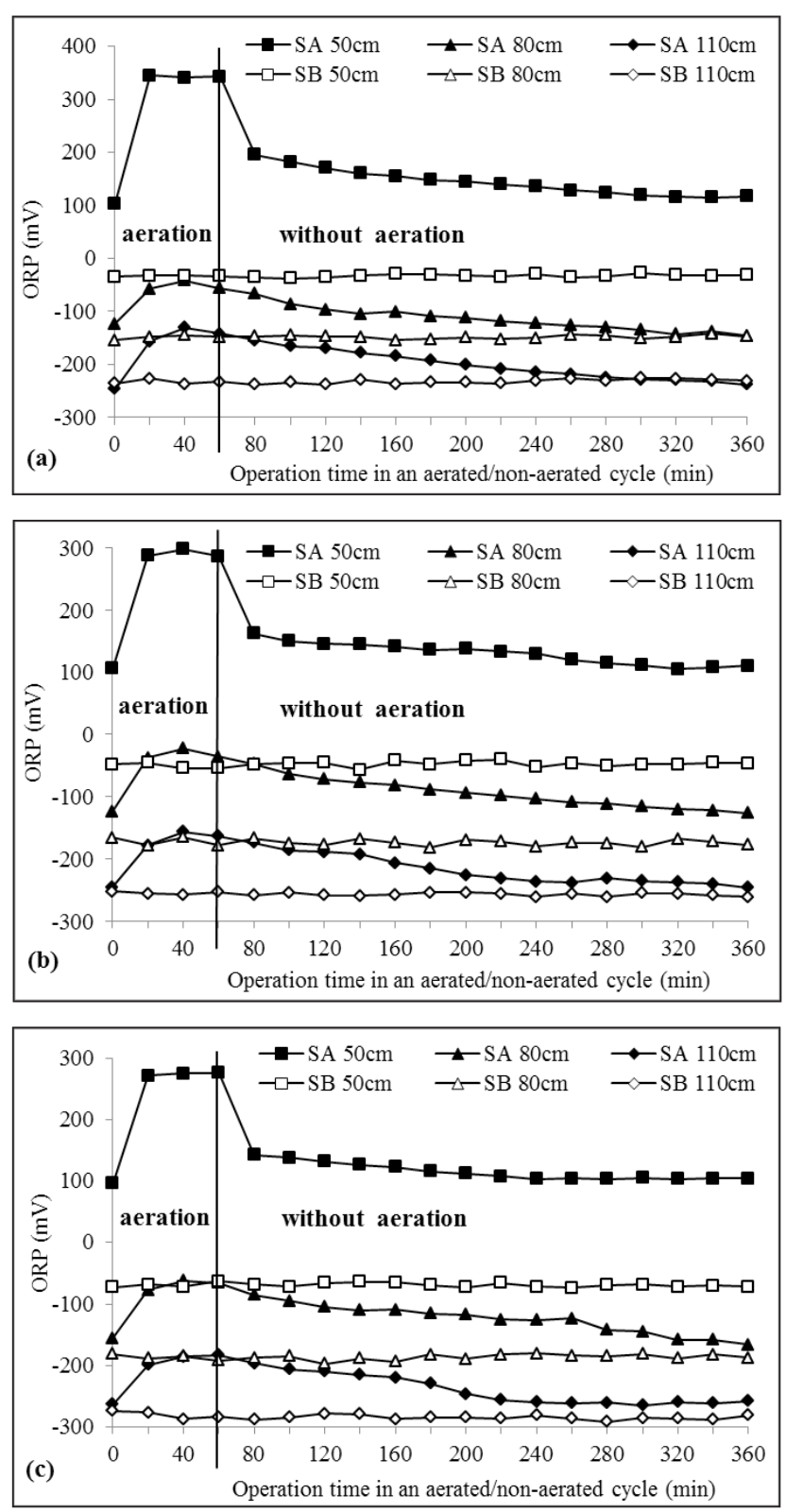

Figure 2

ORP profiles in an aerated/non-aerated cycle in SWISs with intermittent aeration (SA) and without aeration (SB) under organic pollutant loading

(a) $7.4 \mathrm{~g} \mathrm{COD} /\left(\mathrm{m}^{2} \cdot d\right)$, (b) $14.8 \mathrm{~g} \mathrm{COD} /\left(\mathrm{m}^{2} \cdot d\right)$, (c) $29.1 \mathrm{~g} \mathrm{COD} /\left(\mathrm{m}^{2} \cdot d\right)$

decreased COD removal rates in non-aerated SWISs. This result was in accordance with other studies (Fan et al., 2013; Ong et al., 2010). However, COD removal rates were $98.4 \%, 98.1 \%$ and 98.0\% under different organic pollutant loadings ( $\mathrm{a}, \mathrm{b}$ and $\mathrm{c}$ ) in SAs, significantly higher than the corresponding removal rates for SBs $(P<0.05)$. Increasing organic pollutant loading did not affect the efficiency of organic pollutant degradation, which was significantly different between aerated and non-aerated SWISs $(P<0.05)$.

The organic matter degradation process in a SWIS is as follows: after being fed, soil firstly adsorbs organic matter, and then the adsorbed organic matter is gradually converted into low-molecular-weight matter by microorganisms through fermentation and/or respiration, and mineralized as a source of energy or assimilated into biomass (Li et al., 2011). The aerobic heterotrophic bacteria played an important role in the aerobic
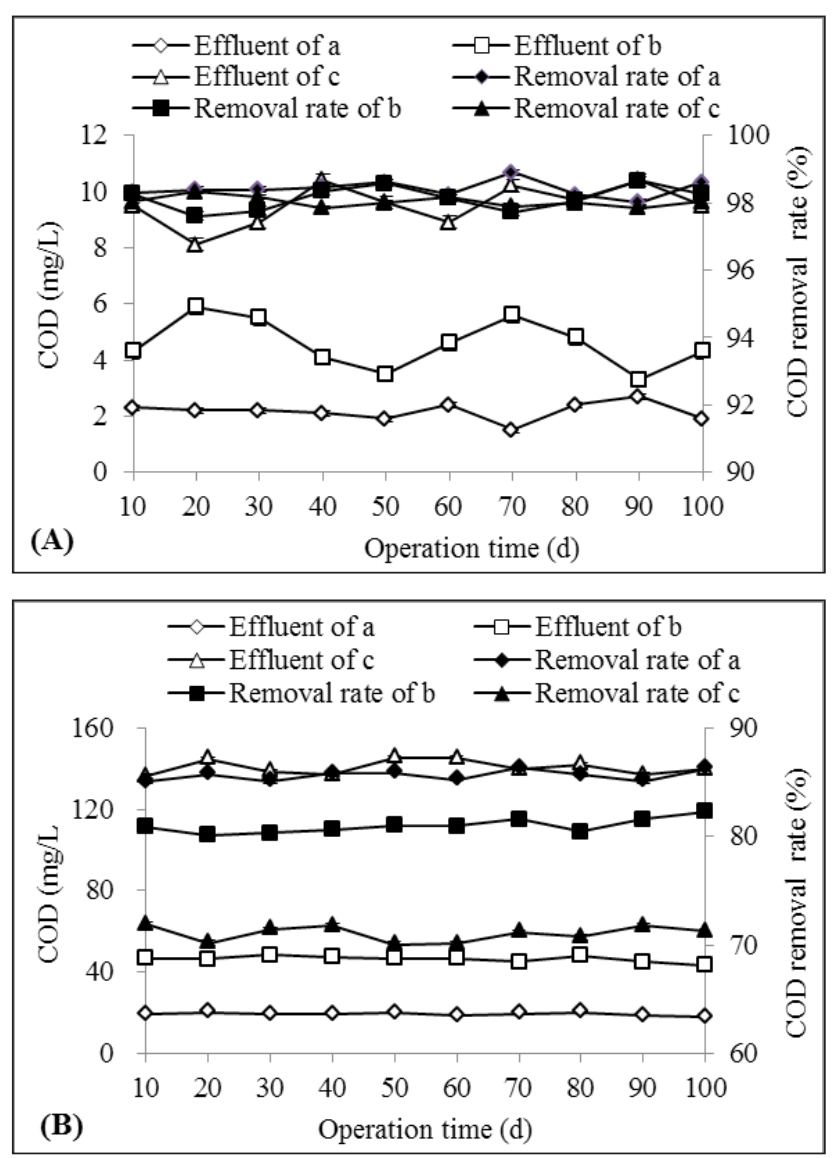

Figure 3

COD profiles in SWISs with intermittent aeration (A) and without aeration (B) under organic pollutant loading (a) $7.4 \mathrm{~g} \mathrm{COD} /\left(\mathrm{m}^{2} \cdot d\right)$, (b) $14.8 \mathrm{~g} \mathrm{COD} /$ $\left(m^{2} \cdot d\right),(c) 29.1 \mathrm{gCOD} /\left(\mathrm{m}^{2} \cdot d\right)$

degradation of organic matter (Wu et al., 2015). Tao et al. (2007) investigated the effects of influent organic strength on heterotrophic bacterial activity, and demonstrated that stronger influent concentration did not result in significant inhibition of heterotrophic activity. The oxygen availability was considered as one of the main rate-limiting factors for organics degradation and nitrification (Fan et al., 2013). Previous studies by Zhang et al. (2005) showed that the oxygen from air diffused into the matrix was limited. Domestic wastewater was richer in dissolved organic matter and a disadvantageous aerobic and anaerobic environment always limited its degradation (Fan et al., 2013). Pan et al. (2015) assessed the removal of organic pollutants in two SWISs and found that supplementary aeration greatly elevated the aerobic biodegradation of organic matter. This study indicated that sufficient oxygen supply could greatly increase the organic matter degradation, with COD removal rates above $98 \%$, even in high organic pollutant load SWISs (such as organic pollutant loading c).

\section{Effects of organic pollutant loading on nitrification performance and $\mathrm{TN}$ removal}

Nitrogen removal mechanisms in the SWIS include soil fixation, nitrification and denitrification, ammonia volatilization and grass uptake, among others (Pan et al., 2015). Of these, nitrification coupled with denitrification was the major removal process (Fan et al., 2013). Complete TN elimination relied first on complete nitrification, which is an aerobic chemo-autotrophic 
microbial process. Most conventional SWISs failed to fulfil this first step due to insufficient oxygen supply. Therefore, nitrification is usually the limiting step for nitrogen removal (MaltaisLandry et al., 2009). As shown in Fig. 4, the average effluent $\mathrm{NH}_{4}{ }^{+} \mathrm{N}$ concentration in SBs was much higher than that of SAs under the same organic pollutant loading. It is widely accepted that nitrification could occur with aerobic conditions $(\mathrm{Wu}$ et al., 2015). Most conventional SWISs fail to achieve efficient nitrification as a result of disadvantageous anoxic or anaerobic conditions for nitrifiers (Fan et al., 2013). In SBs, the DO in the influent was rapidly consumed due to high levels of oxygen demand present in influent wastewaters, which caused an anoxic or anaerobic environment within the substrate and thus seriously
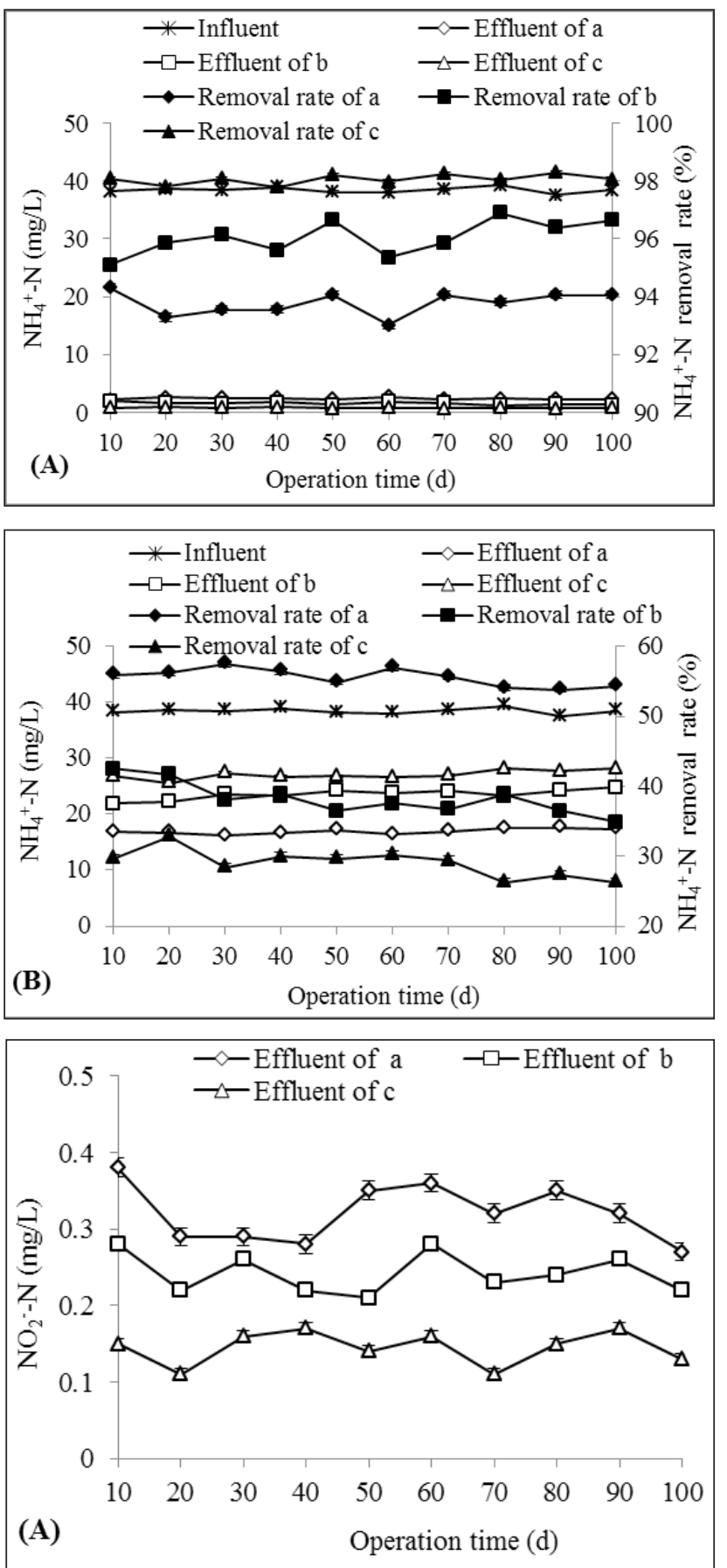

limited $\mathrm{NH}_{4}^{+}-\mathrm{N}$ transformation. Therefore, high average $\mathrm{NH}_{4}^{+}{ }_{-} \mathrm{N}$ concentrations were found in the effluents, which were 16.93, 23.54 and $27.06 \mathrm{mg} / \mathrm{L}$ for organic pollutant loadings of 7.4, 14.8 and $29.1 \mathrm{~g} \mathrm{COD} /\left(\mathrm{m}^{2} \cdot \mathrm{d}\right)$, respectively. As the organic pollutant loading increased from 7.4 to $29.1 \mathrm{~g} \mathrm{COD} /\left(\mathrm{m}^{2} \cdot \mathrm{d}\right)$, the average $\mathrm{NH}_{4}{ }^{+}-\mathrm{N}$ removal rate dropped from $55.6 \%$ to $29.0 \%$. Increased organic matter consumed more available DO and thus further restrained the activity of autotrophic ammonia oxidising bacteria through the greater deficit of oxygen, thus leading to lower levels of nitrification performance.

An intermittent aeration strategy greatly enhanced oxygen supply in SWISs and the oxygen was supplied to the nitrifying microbes of the matrix. A previous study also found that more
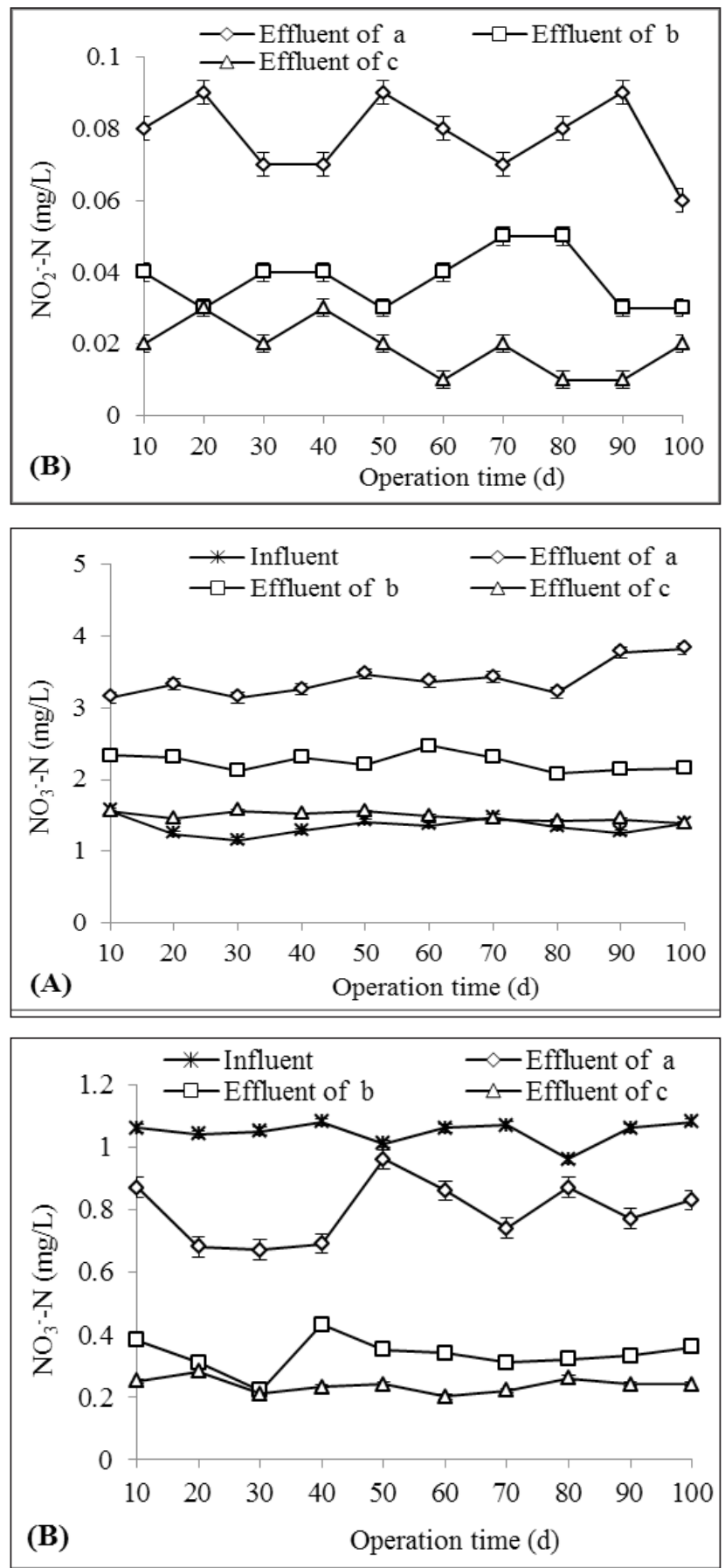

Figure 4

$\mathrm{NH}_{4}^{+}-\mathrm{N}, \mathrm{NO}_{2}^{-}-\mathrm{N}$ and $\mathrm{NO}_{3}^{-}-\mathrm{N}$ profiles in SWISs with intermittent aeration (A) and without aeration (B) 
nitrifying bacteria, other viable bacteria and enzyme activities involved in nitrogen removal were detected in intermittent aerated SWISs than non-aerated SWISs (Pan et al., 2015). In particular, artificial aeration seemed to be the only option to realize nearly complete nitrification when dealing with high-strength wastewater (Wu et al., 2015). As shown in Fig. 4, extremely significant differences between $\mathrm{SAs}$ and $\mathrm{SBs}$ for $\mathrm{NH}_{4}^{+}-\mathrm{N}$ removals were observed under the same organic pollutant loading $(P<0.01)$. Nitrification rates were significantly enhanced in SAs and the $\mathrm{NH}_{4}^{+}-\mathrm{N}$ profiles were almost coincident. The average effluent $\mathrm{NH}_{4}^{+}-\mathrm{N}$ concentrations were $2.41,1.53$ and $0.75 \mathrm{mg} / \mathrm{L}$ for organic pollutant loadings of $7.4,14.8$ and $29.1 \mathrm{~g}$ $\mathrm{COD} /\left(\mathrm{m}^{2} \cdot \mathrm{d}\right)$, and the average $\mathrm{NH}_{4}^{+}-\mathrm{N}$ removal rates in aerated SWISs were $93.8 \%, 96.1 \%$ and $98.1 \%$, respectively. Because of the efficient oxygen supply, excessive organic matter and other oxygen-demanding nutrients seemed not to be a limitation for the nitrification process. Artificial intermittent aeration could greatly improve nitrification performance in SWISs of various organic pollutant loadings. ORP results showed that the oxidative condition of the matrix was improved in upper layers through intermittent aeration in SAs, which was favourable for the nitrification process.

Zhong et al. (2014) reported that alternating areas of aerobic, anoxic and anaerobic conditions facilitated the sequential coupling of nitrification and denitrification, and the nitrite and nitrate generated during the aerobic phase was denitrified in the anaerobic or anoxic phases. However, it would be better if the aerobic conditions occurred in the first and anaerobic or anoxic conditions occurred in the subsequent sections of the matrix. As can be seen in Fig. 4, the average $\mathrm{NO}_{2}^{-}-\mathrm{N}$ effluent concentrations were significantly different between SAs and SBs $(P<0.05)$. Under organic pollutant loadings of 7.4, 14.8 and $29.1 \mathrm{~g} \mathrm{COD/}$ $\left(\mathrm{m}^{2} \cdot \mathrm{d}\right)$, the average $\mathrm{NO}_{2}-\mathrm{N}$ effluent concentrations were 0.08 , 0.04 and $0.02 \mathrm{mg} / \mathrm{L}$ in SBs. Zhang et al. (2006) noted that $\mathrm{NO}_{2}^{-}-\mathrm{N}$ concentrations in the effluent would be between $0.1 \mathrm{mg} / \mathrm{L}$ and $0.5 \mathrm{mg} / \mathrm{L}$, thus indicating a nitrification-denitrification process that was successfully performed in SWISs. In this study, the average $\mathrm{NO}_{2}{ }^{-} \mathrm{N}$ concentrations of the effluent were $0.32,0.24$ and $0.15 \mathrm{mg} / \mathrm{L}$ in SAs under organic pollutant loadings of 7.4, 14.8 and $29.1 \mathrm{~g} \mathrm{COD} /\left(\mathrm{m}^{2} \cdot \mathrm{d}\right)$, which resulted from the intermittent aeration method.

In infiltration systems, $\mathrm{NH}_{4}^{+}-\mathrm{N}$ is firstly adsorbed on the matrix, and then adsorbed $\mathrm{NH}_{4}^{+}-\mathrm{N}$ is transformed to $\mathrm{NO}_{3}^{-}-\mathrm{N}$ by nitrifying bacteria. When the nitrification process ends, $\mathrm{NH}_{4}{ }^{+} \mathrm{N}$ concentration in the effluent declines, while $\mathrm{NO}_{3}-\mathrm{N}$ increases (Fan et al., 2013). The $\mathrm{NO}_{3}^{-}-\mathrm{N}$ must be processed via anaerobic microbial denitrification to be permanently removed from wastewater (Maltais-Landry et al., 2009). Various factors such as insufficient organic carbon source and excess oxygen could limit its completion (Fan et al., 2013). As shown in Figs 4 and 5, TN removal efficiency was far from satisfactory in SBs, and the effluent was still dominated by high concentrations of $\mathrm{NH}_{4}^{+}{ }^{+} \mathrm{N}$ due to limited nitrification. The average effluent $\mathrm{TN}$ concentrations were $17.80,23.91$ and $27.34 \mathrm{mg} / \mathrm{L}$ under various organic pollutant loadings (a, b and c), and the average effluent $\mathrm{NO}_{3}^{-}-\mathrm{N}$ concentrations were very low in SBs due to anoxic or anaerobic conditions. TN profiles of SBs were similar to $\mathrm{NH}_{4}^{+}-\mathrm{N}$ profiles. There is no doubt that nitrification was the limiting step in nitrogen removal in SWISs. SBs could not achieve a high $\mathrm{NH}_{4}^{+}-\mathrm{N}$ removal rate in anoxic or anaerobic conditions, which would greatly inhibit denitrification due to the insufficient supply of $\mathrm{NO}_{3}^{-}-\mathrm{N}$ as electron acceptors. Due to more DO depletion with increasing organic pollutant loading, the TN removal rate dropped from $54.9 \%$ to $31.2 \%$ with an increase in organic pollutant loading
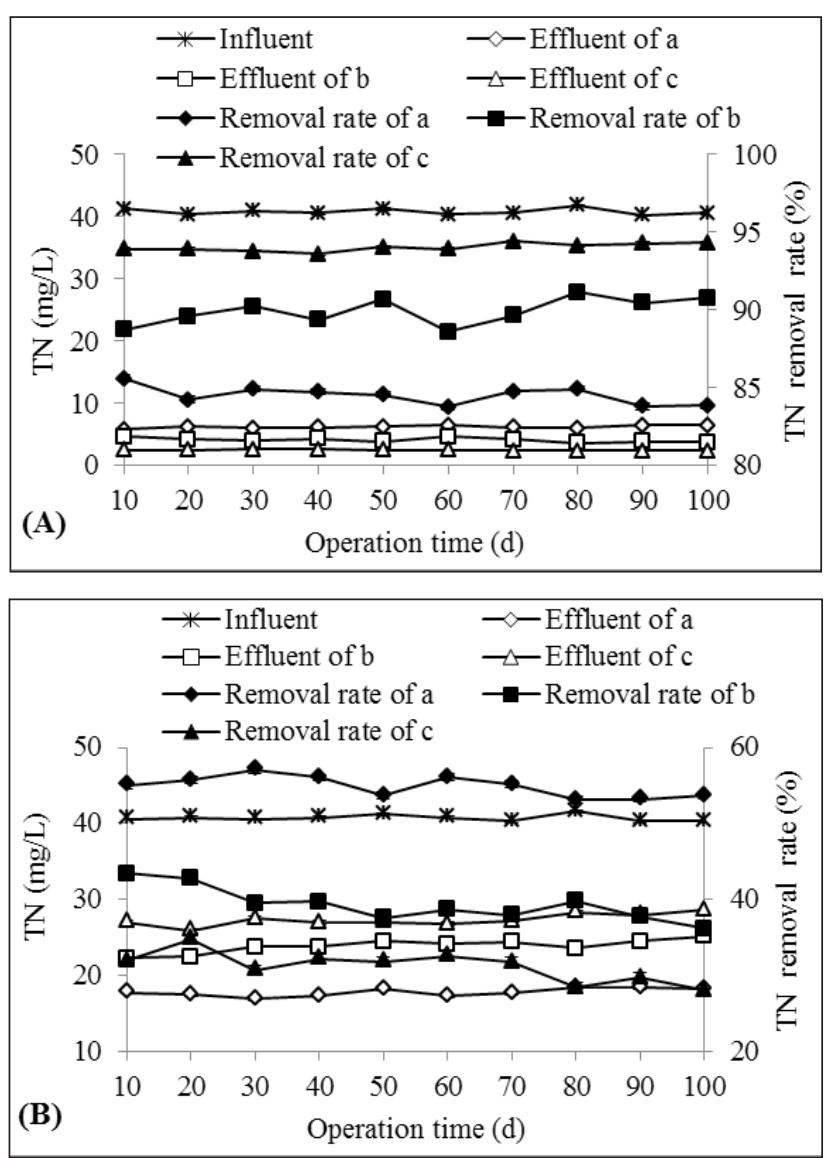

Figure 5

TN profiles in SWISs with intermittent aeration (A) and without aeration (B)

from 7.4 to $29.1 \mathrm{~g} \mathrm{COD} /\left(\mathrm{m}^{2} \mathrm{~d}\right)$, which was similar to the variation in $\mathrm{NH}_{4}^{+}-\mathrm{N}$ removal rate.

According to a study by Zhang et al. (2005), TN removal in conventional SWISs was below $60 \%$ due to their inability to simultaneously provide aerobic conditions and anoxic conditions for nitrification and denitrification. Maltais-Landry et al. (2009) reported that artificial aeration could increase nitrogen removal by $11 \sim 46 \%$. However, in many studies using a continuous artificial aeration strategy, TN removal rates were still not satisfactory although nitrification had been conducted well (Liu et al., 2013). With a sufficient oxygen supply, denitrification usually became the limiting step for effective TN removal due to the lack of anoxic conditions and the depletion of the influent organic matter (Fan et al., 2013). In this study, intermittent aeration was adopted to achieve almost complete nitrification and well-developed aerobic conditions in the upper matrix and anoxic or anaerobic conditions in the subsequent parts of the matrix, in one cycle simultaneously (Fig. 2). After effective nitrification under aerobic conditions, $\mathrm{NO}_{3}^{-}-\mathrm{N}$ and $\mathrm{NO}_{2}^{-}-\mathrm{N}$ as electron accepters could not be removed permanently unless sufficient organic carbon was supplied as electron donor. Carbon deficiency then became the key limiting factor for $\mathrm{TN}$ removal in aerated reactors and $\mathrm{NO}_{3}-\mathrm{N}$ accounted for the major part of the effluent TN (Pan et al., 2015). As shown in Figs 4 and 5, $\mathrm{NO}_{3}-\mathrm{N}$ accounted for the major part of the effluent TN in SAs. There were extremely significant differences in $\mathrm{TN}$ removal between SAs and SBs under the same organic pollutant loading $(P<0.01)$. The average effluent TN concentrations were low in all the intermittently aerated SWISs, which were $6.12,4.02$ and $2.38 \mathrm{mg} / \mathrm{L}$ under organic pollutant loadings of $7.4,14.8$ 
and $29.1 \mathrm{~g} \mathrm{COD} /\left(\mathrm{m}^{2} \cdot \mathrm{d}\right)$. The TN removal rate increased from $84.5 \%$ to $94.0 \%$ with the increase in organic pollutant loading from 7.4 to $29.1 \mathrm{~g} \mathrm{COD} /\left(\mathrm{m}^{2} \cdot \mathrm{d}\right)$. Wu et al. (2015) indicated that influent organic strength would significantly influence the TN removal rates in intermittently aerated infiltration systems, due to high-efficiency nitrification and denitrification simultaneously occurring with high influent organic strength. In this study, high organic pollutant loading could supply sufficient organic matter as electron donor for complete denitrification, and achieved high COD and TN removal rates. The average COD and TN removal rates were all above $98 \%$ and $94 \%$, respectively, in SAs under organic pollutant loadings of $29.1 \mathrm{~g} \mathrm{COD} /\left(\mathrm{m}^{2} \cdot \mathrm{d}\right)$, which was in accordance with the results of other studies (Fan et al., 2013; Wu et al., 2015).

The results suggest that intermittent aeration could be a widespread research and application strategy for achieving high COD, $\mathrm{NH}_{4}^{+}-\mathrm{N}$ and TN removal performance in SWISs under high organic pollutant loading.

\section{CONCLUSIONS}

Matrix ORP results showed that aerobic conditions were effectively developed at a depth of $50 \mathrm{~cm}$ and anoxic or anaerobic conditions were not changed at a depth of 80 and $110 \mathrm{~cm}$ by intermittent aeration, which encouraged nitrification. High removal rates of COD (98.0\% 98.4\%), $\mathrm{NH}_{4}^{+}-\mathrm{N}(93.8 \% \sim 98.1 \%)$ and TN $(84.5 \% \sim 94.0 \%)$ were obtained simultaneously in intermittent aerated SWISs for organic pollutant loadings ranging from 7.4 to $29.1 \mathrm{~g} \mathrm{COD} /\left(\mathrm{m}^{2} \mathrm{~d}\right)$, and these removal rates were significantly higher than for non-aerated SWISs. The results suggest that intermittent aeration is a reliable option to achieve high nitrogen removal in SWISs, especially with high organic pollutant loading.

\section{ACKNOWLEDGEMENTS}

This research was financially supported by the National Natural Science Foundation of China (No.41001321), (No.41471394); Liaoning BaiQianWan Talents Program [2015(45)]; Natural Science Foundation of Liaoning (2015010585-301); Major Original Program in Shenyang Normal University (ZD201403); Ecology and Environment Research Center Director Foundation of Shenyang Normal University (EERC-T-201501, (EERC-T-201601).

\section{REFERENCES}

APHA (American Public Health Association) (2003) Standard Methods for the Examination of Water and Wastewater. American Public Health Association/American Water Works Association/Water Environment Federation, Washington, DC.

DING Y, WANG W, SONG XS and WANG YH (2014) Spatial distribution characteristics of environmental parameters and nitrogenous compounds in horizontal subsurface flow constructed wetland treating high nitrogen-content wastewater. Ecol. Eng. 70 446-449.

FAN JL, ZHANG B, ZHANG J, NGO HH, GUO WS, LIU FF, GUO YY and WU HM (2013) Intermittent aeration strategy to enhance organics and nitrogen removal in subsurface flow constructed wetlands. Bioresour. Technol. 141 117-122.

LI HB, LI YH, SUN TH and WANG X (2012) The use of a subsurface infiltration system in treating campus sewage under variable loading rates. Ecol. Eng. 38 105-109.
LI YH, LI HB, SUN TH and WANG X (2011) Effects of hydraulic loading rate on pollutants removal by a deep subsurface wastewater infiltration system. Ecol. Eng. 37 1425-1429.

LIU L, ZHAO XH, ZHAO N, SHEN Z, WANG M, GUO YZ and XU YB (2013) Effect of aeration modes and influent COD/ $\mathrm{N}$ ratios on the nitrogen removal performance of vertical flow constructed wetland. Ecol. Eng. 57 10-16.

MALTAIS-LANDRY G, MARANGER R, BRISSON J and CHAZARENC F (2009) Nitrogen transformations and retention in planted and artificially aerated constructed wetlands. Water Res. 43 535-545.

ONG S, UCHIYAMA K, INADAMA D, ISHIDA Y and YAMAGIWA K (2010) Performance evaluation of laboratory scale up-flow constructed wetlands with different designs and emergent plants. Bioresour. Technol. 101 7239-7244.

PAN J, FEI HX, SONG SY, YUAN F and YU L (2015) Effects of intermittent aeration on pollutants removal in subsurface wastewater infiltration system. Bioresour. Technol. 191 327-331.

TAO W, HALL KJ and RAMEY W (2007) Effects of influent strength on microorganisms in surface flow mesocosm wetlands. Water Res. 41 4557-4565.

WU HM, FAN JJ, ZHANG J, NGO HH, GUO WS, HU Z and LIANG S (2015) Decentralized domestic wastewater treatment using intermittently aerated vertical flow constructed wetlands: Impact of influent strengths. Bioresour. Technol. 176 163-168.

ZHANG J, HUANG X, LIU CX, SHI HC and HU HY (2005) Nitrogen removal enhanced by intermittent operation in a subsurface wastewater infiltration system. Ecol. Eng. 25 419-428.

ZHANG ZY, LEI ZF, ZHANG ZY, SUGIURA N, XU XT and YIN DD (2006) Relationship between variation of nitrite-nitrogen concentration and removal efficiency for soil aquifer treatment process. J. Fudan Univ. 45 755-758.

ZHONG F, WU J, DAI YR, CHENG SP, ZHANG ZH and JI HZ (2014) Effects of front aeration on the purification process in horizontal subsurface flow constructed wetlands shown with $2 \mathrm{D}$ contour plots. Ecol. Eng. 73 699-704. 